\title{
Anti-corruption education as an effort to form students with character humanist and law-compliant
}

\author{
Jagad Aditya Dewantara ${ }^{1}$, Yudi Hermawan ${ }^{1}$, Dadang Yunus ${ }^{2}$, Wibowo Heru Prasetiyo ${ }^{3}$, Efriani ${ }^{1}$, Fitria \\ Arifiyanti ${ }^{4}$, T Heru Nurgiansah $^{5}$
}

${ }^{1}$ Pancasila and Civic Education Study Program, Universitas Tanjungpura, Pontianak, Indonesia

${ }^{2}$ Civic Education Department, Universitas Pendidikan Indonesia, Bandung, Indonesia

${ }^{3}$ Pancasila and Civic Education Study Program, Universitas Muhammadiyah Surakarta, Surakarta, Indonesia

${ }^{4}$ University of Szeged, Hungary

${ }^{5}$ Pancasila and Civic Education Study Program, Universitas PGRI Yogyakarta, Yogyakarta, Indonesia

\begin{abstract}
Anti-corruption education has a role in solving the problem of corruption. We can see from the increasing number of corruption cases that display on various social media. This phenomenon must prevent and eradicate the country's economy, national values, and state ideology. This article examines anticorruption education as character building that emphasizes free will, individual behavior through student potential. This study conducted using qualitative methods and literature study with the object of analysis from various references to books, articles, and other media. The approach to this research uses normative-empirical methods as the basis for analyzing primary and secondary data. The results obtained were that anti-corruption education for students required the formation of a humanistic character, student knowledge about corruption, legal policies related to corruption cases and obedience and legal awareness of students in tertiary institutions to maintain a caring attitude towards the nation and state.
\end{abstract}

Article History:

Submitted : :31-01-2021

Revised : :09-02-2021

Accepted : :06-03-2021

Keywords:

education, anti-corruption, character, humanist

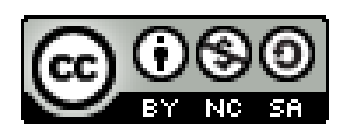

Cite in APA ${ }^{\text {7th: }}$

Dewantara, J. A., Hermawan, Y., Yunus, D., Prasetiyo, W. H., Efriani, E., Arifiyanti, F., \& Nurgiansah, T. H. (2021). Anti-corruption education as an effort to form students with character humanist and law-compliant. Jurnal Civics: Media Kajian Kewarganegaraan, 18(1), 70-81. https://doi.org/10.21831/jc.v18i1.38432

\section{Introduction}

Progress in education, especially in higher education, is a shared task for all components, including students. As agents of change, students are not required to be successful in the academic field and have to have character attitudes that can change the nation for a better direction. Character education can obtain one of the perspectives of the character. Character education is the right solution for the younger generation to determine their identity to avoid negative behavior such as corruption (Salistina, 2015). Progress in education, especially in higher education, is a shared task for all components, including students. As agents of change, students must be successful in the academic field and have character attitudes that can change the nation for a better direction. Character education can obtain character attitude. Character education is the right solution for the younger generation to determine their identity to avoid negative behavior such as corruption (Prasetiyo et al., 2020).

However, the facts in the field, there are complex problems among students. Most of them only focus on being able to complete their studies on time. The reasons vary, ranging from saving 
costs and aging to returning to their respective hometowns quickly. So that there are terms such as Butterfly Student (Going Home-Going Home). A phenomenon like this gives rise to an individualistic attitude and justifies any means to finish his studies immediately. It is not uncommon for specific graduation requirements to be manipulated to pass verification to take the final exam. That is a behavior that injures sportsmanship (Nurgiansah, 2021). In other words, practices of corruption, collusion, and nepotism are commonplace in universities.

Corruption in Indonesia has fallen into social life and government, rooted in life habits, social behavior, and people's way of thinking (Kristiono, 2018). In short, corruption is defined as embezzling funds for personal gain. This phenomenon is increasingly taking place dynamically and growing so fertile that corruption is seen as a crime that can undermine the Indonesian nation (Arliman, 2017).

Anti-corruption has an essential role in solving problems related to acts of corruption. Judging by the increasing number of corruption cases exhibited on various social media in Indonesia, the crime must be prevented and eradicated. It does not affect the Indonesian nation's value order, which refers to the state ideology (Eliezar, 2020). A high level of corruption can result in obstruction of the socio-cultural and economic formation in Indonesia.

A study Sumaryati (2020) revealed that Indonesia achieved a corruption perception index of 40 out of a maximum of 100 and was in the 85 th rank of 180 countries surveyed in 2019 . Separate from Arliman (2017) that the Indonesian state is ranked as the most corrupt in the survey conducted, there are prominent reasons for Indonesia's corruption. First, qualitatively, it indicates corrupt practices in various institutions, including in tertiary institutions, which involve students. Second, it is substantially challenging for the public to distinguish between corruption and their habits so that corrupt people's behavior is considered normal. Third, most government officials carry acts of crime, such as DPR members, ministers, and regents.

The government applies several ways and strategies to shape the younger generation's character to not fall into acts of corruption, namely fostering moral education in the family, guiding law enforcement, and promoting government officials (Djalali, 2008). This coaching activity must be carried out continuously to make all parties aware of corruption's latent dangers, for example, in various universities, including Anti-Corruption Education courses in the curriculum or by inserting anti-corruption material in Pancasila and Citizenship Education courses. That is in line with efforts to prevent corruption acts, namely the need to instill an anti-corruption character through anti-corruption education courses (Kristiono, 2018).

Another solution is inculcating anti-corruption values in higher education institutions as a preventive measure to prevent corruption (Suryani, 2017). These preventative measures are more humane than repressive measures. Because after all, prevention is better than repression or punishment.

Besides, eradicating corruption can be done using an anti-corruption movement (Widoyoko, 2016). There is a way to prevent bribery acts by forming an anti-corruption character instilled through an anti-corruption culture, increasing legal awareness, and cultivating students' integrity in various universities.

Higher education as an intellectual spearhead for students becomes a forum for character building and character. It can instill anti-corruption thought patterns, attitudes, and behaviors through the college's learning process (Suryani, 2017). Students' involvement as a bridge between society and the government can make anti-corruption education in tertiary institutions and society's social strata. 


\section{Method}

This article describes several aspects of anti-corruption education in forming character, humanist, and law-abiding students in higher education. This analysis uses the empirical normative legal research method because sampling and data are carried out using a combination of the normative legal approach, which is added with various empirical elements in today's social life. This empirical normative legal research method is basically a combination of the normative legal approach with various empirical elements in this study. We do data analysis in this research by taking normative legal provisions (laws), legal, scientific articles relating to their actions in every Law-Compliant event in an event in society. Armytage (2010) categorizes this into three: nonjudicial case study, judicial case study, and live case study.

Table 1

Research stage, Normative Law, and Empirical Law

\begin{tabular}{|c|c|c|c|}
\hline Method & Research Stage & Normative Law & Empirical Law \\
\hline \multirow[t]{3}{*}{ Normatif-Empiric } & Approach method & $\begin{array}{l}\text { Normative/juridical, the law is } \\
\text { identified as a regulatory or } \\
\text { statutory norm (UU) }\end{array}$ & $\begin{array}{l}\text { Empirical/sociological, } \\
\text { the law is identified as } \\
\text { patterned behavior }\end{array}$ \\
\hline & $\begin{array}{l}\text { Theoretical } \\
\text { framework }\end{array}$ & $\begin{array}{l}\text { Internal theories about law } \\
\text { such as laws (UU), } \\
\text { government regulations. } \\
\text { Evidence through articles. }\end{array}$ & $\begin{array}{l}\text { Social theory regarding } \\
\text { the law or sociological, } \\
\text { legal theory. Proof } \\
\text { through society. }\end{array}$ \\
\hline & Data & $\begin{array}{l}\text { Using secondary data (data } \\
\text { obtained from library } \\
\text { research) }\end{array}$ & $\begin{array}{l}\text { Using primary data } \\
\text { (data obtained directly } \\
\text { from people's lives } \\
\text { utilizing interviews, } \\
\text { observations, } \\
\text { questionnaires, } \\
\text { samples, and others) }\end{array}$ \\
\hline
\end{tabular}

Based on table 1, we take the research object based on positive law aspects and then relate it to the applicable positive law. This data collection technique uses literature study techniques by collecting several legal reference sources related to empirical symptoms in the student environment. The basis of this research analysis is obtained from norms, jurisprudence, and doctrine as a study of normative methods. As for the empirical analysis, we use legal sociology, legal anthropology, psychology, or inductive social theory. Therefore, the form of analysis obtained is in the form of normative logic (based on logic and laws), syllogism (drawing existing conclusions), qualitative to conclude, and the results of this study.

\section{Results and Discussion}

\section{Anti-Corruption Education in Building Character}

Student characters that are expected to emerge through anti-corruption education include religious, honest, and responsible names. The spiritual name means forming a sense of faith and devotion to an almighty god so that fear arises and feels watched in every student movement. Religious character is included in a spiritual environment such as a boarding school and a public domain. Religious activities can awaken students to continue to behave by religious norms.

Furthermore, an honest character becomes the benchmark for anti-corruption education in higher education. Plain speaking will go hand in hand with honesty in action. Honesty will also prevent students from manipulative behavior in lectures. Honest in doing assignments, natural in 
carrying out written examinations, and open in admitting all mistakes that have been made by regretting them.

Moreover, the third is responsible for himself, others, and responsibility for the environment. Responsibility towards oneself means treating oneself according to one's level or according to human dignity, not injuring and tormenting oneself by imposing burdens that exceed one's ability. Responsibility towards others means treating each other well, not bullying.

Anti-corruption education learning in tertiary institutions is generally not included in the learning curriculum. Still, it is only limited to part of the Pancasila Education and Citizenship Education courses' material. Specifically, the learning carried out in anti-corruption education includes: First, students' intellectual ability to think critically and be active in responding to the phenomena in this country to deepen their thoughts' literacy. Second, students' ability to control themselves is needed to act by their literacy and not be arbitrary towards others. Third, the essential knowledge that is owned to be a benchmark in action.

Anti-corruption is prevention against money laundering and bribery which are classified as criminal law. Regarding the prevention of corruption, a government contribution is needed to overcome this corruption act. The ancient central spear for preventing crime is in education for the younger generation to not fall into corruption. Anti-corruption education leads to the formation of a person's character, attitude, and character to stay away from crime acts as a strategy to prevent crime. According to Eliezar (2020), Anti-corruption education fosters honesty, caring, self-discipline, responsibility, hard work, courage, fairness. Unlike Salistina (2015), anticorruption education is carried out informal education so that students can distinguish forms of crime from corruption from other forms of crime.

A study explained that anti-corruption education is essential for students and students to learn about corruption to sharpen their understanding of crime. Crime also has a personal (individual) and community (group) structural, and this is difficult to eradicate when the actions are carried out in an organization. Because, of course, there is a game in the structural realm of existing legal policies. Even though the law used is strict, the decisions to be taken are not necessarily fair. Other than that, Sumaryati (2020) reveals that anti-corruption education is one way to overcome the occurrence of acts of corruption carried out in learning at schools, in organizations, and in the social environment. Anti-corruption education in school learning includes value education that needs to be cultivated from toddlers to adolescents, and this is included to prevent acts of corruption for students by providing good habits in developing value education.

The implementation of anti-corruption education as the formation of student character on campus should be done in three ways, namely: (1) integrating anti-corruption education into courses, (2) integrating into material content in several classes, and (3) integrating anti-corruption education with student self-development. Anti-corruption education as forming student character through these three ways is an introduction to general values contained in Pancasila, which aims to internalize the fundamental importance of Pancasila into student behavior through the learning process, both on and off-campus (Baez-Camargo et al., 2017; Fitriyah \& Permatasari, 2020).

As stakeholders on campus, students have an essential role in changing this country, as a bachelor's degree known as agents of change has broad potential and knowledge. Other than that, (Hasan, 2016; Kristiono, 2018) The importance of anti-corruption education for students can be integrated into Pancasila, civic education, and moral education. Seen at the student level, the establishment of anti-corruption and relevant subjects, anti-corruption education can also be realized in activities outside the campus/extracurricular activities such as by holding anticorruption socialization through mass media and others. In anti-corruption education, learning is 
directed at character building as a foundation in the formation of values already contained in anticorruption education itself; these values have been instilled through moral value education. Besides, moral value education is included in the same character-building domain as anticorruption education. The weights that must be invested in students have the importance of honesty, the value of care, the value of independence, the value of discipline, the value of responsibility, the value of hard work, the value of simplicity, the value of courage, and the value of justice (Cahyono et al., 2020; Kristiono, 2018).

Students are the most excellent resource in shaping self-character because students are considered a group of people who have good morals and become social control for society's social life. Students' knowledge about anti-corruption is obtained from education while in college, including student knowledge about the process of eradicating corruption. Anti-corruption values must continue to be instilled in students to have the competence and prevent crime by others. Students' character-building obtained from anti-corruption education can be seen from students' courage to take various forms of corruption prevention while on campus, in their families, and in social settings. The roles of lecturers, staff, chancellor, and all those involved in the formation of anti-corruption character in students must work hand in hand in creating a robust anti-corruption character (Hidayat, 2019; Kadir, 2018).

Anti-corruption education provided to students is education which means that they are part of the citizens who deliver the nation's future and state, especially in eradicating Indonesia's corruption. The characteristic of anti-corruption education is that there is a need for a link between information and knowledge regarding moral considerations related to existing corrupt acts (Hauser, 2019; Indawati, 2015). The anti-corruption learning process applies several strategic approaches, which can activate students both physically and psychologically. Several learning approaches to anti-corruption character education include: (1) Value analysis approach, (2) Value planting, (3) Value clarification, and (4) Can also be developed through learning through dialogue, discussion, problem-solving, discovery, and methods adapted to the limitations of space, time, and conditions. Anti-corruption character education aims to develop students' capacities and capabilities (moral knowing, moral feeling, and moral action) (Kadir, 2018; Komalasari \& Saripudin, 2015).

The value of honesty will shape students' character to be trustworthy in their trust and never lie. Students should own the importance of openness; without a real name, students will be excluded and cannot be trusted in society's social life. Honesty in campus life is essential because honesty is an authentic proof that their peers can charge students. When students commit dishonesty, they will be judged as students who keep on lying. Therefore, honesty is the key to be trusted by others.

Furthermore, Caring's value and value of caring are significant for students on their campus and social life activities. Students as a bridge of communication with the community and government. Students must have a sense of care for this country. The campus is the second home to sharpen insights and lead to good behavior towards society and the government. Students, as future leaders, need to have a caring value in paying attention to the campus environment and the surrounding environment. Self-maturation to be able to hold fast to his mandate as a student. The value of caring also needs to be applied by students when a natural disaster occurs.

Then the value of independence, this value needs to be possessed by students to strengthen their responsibilities and efforts to carry out their desires without others' help. Independent in doing assignments from lecturers and independent in solving lecture problems both in academic and non-academic spheres. 
The value of discipline is an attitude that every student must have to foster obedience, responsibility, and consistency with higher education institutions' regulations. This discipline's formation is considered necessary for students to manage their time, leading to benefits and leads to effectiveness, and efficiency in various matters.

The value of responsibility is a person's character or an obligation to bear and assume responsibility. If students do not have a sense of responsibility, they will neglect to carry out their duties and responsibilities. However, when students have a sense of responsibility, they are more likely to complete the task optimally. Commitment is owned by the desire or effort to get something.

The value of hard work in achieving success and a mature will are things that students must have. Hard work will lead to perseverance, determination, self-control, courage, fortitude, and strength. For students, the character building of hard work is significant in achieving the results they desire. Hard work is the primary key for students to complete their studies. Few students stop halfway before completing their tasks due to feeling lazy, pessimistic, and instant ways contrary to university statutes.

Furthermore, the value of simplicity is the basis for student behavior and lifestyle to live. Students are given assumptions to minimize royal and hedonistic actions and act according to the square in fulfilling their life's needs - simple means not pushing themself to get the same things with other people. Therefore, a mature mind is needed to weigh prioritized needs and put aside the desires one has.

The value of courage must be instilled in the student's soul to become someone tough in running the wheels of life. As a student, he must have the determination to instill a commitment to achieve the desired goals. Students need the courage to accept the consequences when failure is experienced and get happiness if their efforts result in success.

Finally, the value of justice this value is used as a benchmark for deciding a wise action. The word fair is used as an equal, impartial, and impartial decision to anyone. A fair character needs to be instilled by the lecturer to learn and act fairly and wisely without being harmed.

\section{Establishment of a Humanist Attitude through Anti-Corruption Education}

Student humanist behavior is one of the diversity of anti-corruption educational goals that aim to maturing humans by teaching / educating based on humanist values to maintain human existence, dignity, and dignity (Idris \& ZA, 2017). The humanist values include the importance of freedom, creativity, desire, cooperation, confidence, morals, and responsibility.

Humanist values cannot be separated from a humanist attitude centered on humanity and are related to one another. As part of individualistic character traits, humanist values can encourage the group's individualist attitude to become a nation's unifier. The importance and humanist perspectives as a form centrally to revive a sense of humanity and aspire to the country's integrity based on the paradigm of the values of Pancasila. Humanist values include: 1) respect for the opinions of others; 2 ) cooperation; 3 ) willingness to sacrifice; 4) care for others; 5) please help and 6) solidarity. In humanistic values, students are directed to be able to appreciate arguments and contributions to the thoughts of others, have a solid determination to build togetherness as a group, and have a caring attitude towards others as a form of humanity and can provide help to the people around them (Pritaningtias et al., 2019; Sarmini et al., 2018).

Character building starts from thinking and behaving that characterizes each individual to interact in an external, social and national environment (Setiawan, 2013). In Lickona (2009) study, character education deliberately shapes a person to understand, pay attention to, and carry out 
core values. Humanistic education is education as an individual approach to think positively and act positively through real-life (Rachmahana, 2008); this can encourage individuals to continue learning in a structured manner and keep up with the changing times. A study that describes character education as a fundamental education in its application requires students to understand anti-corruption education, paying attention to acts of corruption that can harm the perpetrator, the nation, and the state.

Humanistic education is in line with anti-corruption teaching to instill one's morals and become a foundation in forming real identity and attitude based on the Pancasila paradigm, the 1945 Constitution the national education system.

Idris and ZA (2017) revealed that anti-corruption education requires a model for developing anti-corruption education in a humanistic perspective in schools and colleges, including: first, developing and cultivating positive values. Second, have good morals and character. Third, have an attitude of empathy and work hard. Fourth, have a good personality with anti-corruption education objectives to measure students' positive values in their thoughts and feelings. Students need to have an anti-corruption education development model to foster morale towards peers, behave well, and instill a positive attitude towards students in the campus environment and the social community. Students have the stand and commitment to remain agents of change for the community, nation, and state.

Higher education is one factor that can affect the success of applying anti-corruption values in the student environment. The application of anti-corruption behavior in tertiary institutions to students can be obtained from good examples by their educators as the most effective means of developing expected anti-corruption values, attitudes, and behaviors. Anti-corruption education is the habituation of the acculturation process, institutionalizing and strengthening anti-corruption values by higher education rules. The habit of implementing an anti-corruption attitude needs to be created in various situations and conditions that aim to improve the character values or characteristics of students. Patterns are not the result of the student's maturation process but result from experience or learning and behavior repeatedly to respond to the student's stimulus (Marlina et al., 2020; Serfontein \& Waal, 2015).

The development of anti-corruption material is one of the efforts that must be made by educational institutions that are integrated into learning tools. The purpose of this learning is to foster the character of the younger generation in thinking critically about global issues so that they can explore, develop, express values and prepare them to tackle corruption (Project Against Corruption in Albania (PACA), 2012; Sofwan et al., 2018; Subkhan, 2020). Anti-corruption education for students aims to develop their ability to understand the nation's problems that trigger corruption, the impact of crime, prevention of bribery, and resolution of corruption. The education system taught to students about eradicating corruption is an educational system that starts with simple things, such as discipline or not being late for college, giving gifts or gratuities to lecturers, misuse of scholarship funds, plagiarism, cheating, making false proposals, leaving absences. The implementation of anti-corruption education is expected to change the attitudes and behaviors that students previously owned towards a change in positive attitudes. For example, a change in students' mindset who consider the slightest cheating attitude in the exam is an evil deed. As well, students who do lecturer's assignments by copying and pasting selections belonging to friends who are recognized as their jobs are a natural thing to happen to be changed to even if they are wrong, but studies are still done independently as a process of learning (Mahpudz, 2020; Manurung \& Heliany, 2020). 
The output of anti-corruption education obtained by students at the tertiary institutions where they study is the growth of students' active participation in preventing corrupt practices by participating in building an anti-corruption culture in society.

\section{Legal Policies in Handling Corruption}

Policy in legal management is formulated with all government officials' consent involved in making standard rules and then announced to all Indonesian people. Traditional approaches are made to be able to build a regular and harmonious life together. When the stipulated law rules are proper, the policies taken by the law enforcement government officials are not fair. Then it will have an impact on a slumping economy. Legal authorities must obey all people and government officials because the law must be enforced and strengthen the rules. So that all people and government officials are afraid to commit acts of corruption.

However, corruption cases in this country are difficult to eradicate because government officials reflect on the public's corruption. If actions are to be destroyed, the government must take extra measures related to anti-corruption education and become a fair reflection of avoiding acts of corruption. In the legal policies stipulated in the Law on Eradicating Criminal Actions of Corruption, it is emphasized that corruption law policies lead to criminal acts that can harm other people, social rights, the community's economy, and obstruct the country's development sector. Law enforcement regulations related to acts of corruption have been conditioned by Law no. 31 of 1999 before, had quite significant differences from the current law. Especially in the regulations related to reducing sanctions for judges who accept bribes. The previous rule stated that a judge who received a fix was sentenced to 4-20 years, but the sentence was 1-7 years under the conditional regulation. The legal policies related to eradicating corruption should be more explicit to prevent corruption acts by government officials. Thus, these rules can become a basis for perpetrators to avoid acts of corruption by looking at the firm and indiscriminate practices.

The law should be made to protect the community's interests, not protect a few individuals who commit acts of corruption. Besides, the law must have a deterrent effect so that others do not imitate similar behavior. The person who has committed the crime can regret his actions and be determined not to repeat them.

Furthermore, about the previously conditioned rules, with the regulations that are now in effect, it has a more noticeable difference in the threat of the death penalty, which was yet regulated. Still, for the current regulation, it has been removed. Besides, the rules on assets that previously governed embezzlement of funds, conflicts of interest, and improper reporting have also been removed.

The rules that have been removed are classified as regulations to reinforce the prevention of corruption. Even though the previous rules were more extreme, with these regulations, the state apparatus and society could stay away from acts of bribery and felt afraid to commit acts of corruption. When the rules that are made provide more security for government officials to achieve breakdown, they are not just rules but also rules favoring the government. People feel cornered because the rules are made to prioritize prevention in general, not specifically for government apartments that are easier to carry out corruption cases, by previous acts of corruption that government officials more predominantly carry out.

Rules regarding the conditioned acts of corruption, legal policies should be made to be obeyed and prosecute without siding with anyone. Therefore, the regulations in preventing crime must be affirmed by all government officials, not only for the people, but the law is also sharp downward and sharp and upward, not taking sides because the rules are implemented together to create the welfare of society, nation, and state. 
Corruption crimes must also be categorized as extraordinary crimes because their inflicted damage is very severe and targets all aspects of life, such as economic, social, political, and legal. In the financial sector, corruption causes the country to suffer losses. In social terms, the perpetrators of crime receive social sanctions in the form of exclusion. In the political field, the stability of democracy is threatened, and public trust in political figures has decreased, resulting in low public participation in practical political activities. The apathy of society in the political field is allegedly due to political figures who are fond of corruption. Moreover, in a legal system, corrupt behavior can mess up law enforcement. Law enforcers such as the judiciary and the prosecutor's office have even been involved in corruption acts.

\section{Awareness and Obedience of Student Law Against the Latent Dangers of Corruption}

Awareness of the rule of law is very influential on actions to comply with applicable legal regulations. When the rules set are excellent and fair without taking sides with anyone. Legal awareness can be measured by how much knowledge of the law is and how well the behavior is reflected in one's personality in obeying the applicable regulations (Nurgiansah et al., 2020). It requires public awareness of the law so that it can be observed and followed. The law is made as a foundation in managing the state, in other words, to be able to guarantee legal certainty in the life of the people of the nation and state. Therefore, students have an essential role in providing direction on the applicable law. So that people can have an awareness of the law and not arbitrarily behave towards others.

Legal awareness of corruption is also needed to prevent acts of corruption. When the public attends that crime is despicable behavior that must be avoided, the public will stay away from acts of corruption and have the awareness not to commit acts of corruption that can become obstacles in advancing the country. The formation of student character to be aware of legal rules is the main goal in anti-corruption education as prevention against the young generation and shaping students' names as not to fall into corrupt behavior (Kamaruddin, 2016). Thus, it affects behavior as a good culture for each individual and does not lead to corruption acts.

Besides, the emergence of student legal awareness will impact law obedience; when students are aware of the law, they will obey all applicable standard rules. However, if students do not know the law, they will violate all relevant legal regulations. Therefore, legal awareness and legal compliance must be instilled simultaneously to avoid violations of the law. Kamaruddin (2016) revealed two kinds of law: first, legal awareness and legal compliance are within the scope of standard rules by applicable legal regulations to be realized. Second, legal awareness in the form of opposing the law and breaking the law.

The law is an obligation that must be obeyed; students as intellectuals can abide by the rules of law instilled in every student to have legal awareness and obedience. Besides, students must abide by standard regulations to form characteristics in preventing corruption and studying more formally, non-formally, and informally related to anti-corruption education as a form of habituation in realizing good character.

Indicators in legal awareness are reflected in 4 things: knowledge of the law, understanding of the law, attitudes, and behavior towards the law itself. Students' knowledge and experience of the laws that govern corruption can be obtained through regular lectures or seminars. Meanwhile, his attitudes and behavior are reflected in students' daily habits, such as avoiding cheating, plagiarizing, and jockeying. Better knowledge and understanding of students towards the law will have an impact on their attitudes and behaviour. 


\section{Conclusion}

Anti-corruption education is taught to form students with character, humanist, and lawabiding character. Student characters developed inexperience, care, independence, discipline, responsibility, hard work, modesty, courage, and fairness. Students' humanistic attitude is reflected in daily behavior in lectures, such as being polite to lecturers, being friendly and courteous to others, and caring for the environment. Students' law-obedient attitude is reflected in their behavior that is far from corruption, collusion, and nepotism.

\section{References}

Arliman, L. (2017). Konsep dan gagasan pengenalan pendidikan antikorupsi bagi anak dalam rangka mewujudkan generasi yang bebas korupsi. Nurani: Jurnal Kajian Syari'ah Dan Masyarakat, 17(1), 49-64. https://doi.org/10.19109/nurani.v17i1.1348

Armytage, L. (2010). Judicial reform in Asia: Case study of AusAID's experience in Papua New Guinea: 2003-2007. Journal of Development Effectiveness, 2(4), 442-467. https://doi.org/10.1080/19439342.2010.525811

Baez-Camargo, C., Bukuluki, P., Lugolobi, R., Stahl, C., \& Kassa, S. (2017). Behavioural influences on attitudes towards petty corruption. A Study of Social Norms and Mental Models in Uganda (Issue December). Switzerland: University of Basel.

Cahyono, Mulyana, D., \& Sukarliana, L. (2020). Growing the character of responsibility in students through teacher's exemplary in anti-corruption education efforts. Proceedings of the 2nd Annual Civic Education Conference (ACEC 2019), 418, 67-72. https://doi.org/10.2991/assehr.k.200320.013

Djalali, M. A. (2008). Upaya mencegah perilaku korupsi melalui pendidikan. Tadris: Jurnal Pendidikan Is/am, 3(1), 85-92. https://doi.org/10.19105/tjpi.v3i1.225

Eliezar, D. (2020). Pendidikan anti korupsi dalam budaya Jawa. Scholaria: Jurnal Pendidikan Dan Kebudayaan, 10(1), 66-72. https://doi.org/10.24246/j.js.2020.v10.i1.p66-72

Fitriyah, M. A. T., \& Permatasari, N. A. (2020). Anti-corruption behavior education for children to prevent corruption as extraordinary crime in the city of Surabaya. 4th International Seminar of Research Month, 75-83. https://doi.org/10.11594/nstp.2019.0411

Hasan, R. (2016). Penerapan pendidikan anti korupsi di kampus sebagai bagian integral dari pendidikan karakter. EDUKASI, 13(2), 313-327. https://doi.org/10.33387/j.edu.v13i2.51

Hauser, C. (2019). Reflecting on the role of universities in the fight against corruption. RAUSP Management Journal, 54(1), 4-13. https://doi.org/10.1108/RAUSP-09-2018-0080

Hidayat, A. S. (2019). Pendidikan kampus sebagai media penanaman nilai-nilai antikorupsi bagi mahasiswa. SALAM: Jurnal Sosial Dan Budaya Syar-I, 6(1), 43-54. https://doi.org/10.15408/sjsbs.v6i1.10498

Idris, S., \& ZA, T. (2017). Realitas konsep pendidikan humanisme dalam konteks pendidikan Islam. JURNAL EDUKASI: Jurnal Bimbingan Konseling, 3(1), 96-113. https://doi.org/10.22373/je.v3i1.1420

Indawati, N. (2015). The development of anti-corruption education course for primary school teacher education students. Journal of Education and Practice, 6(35), 48-54.

Kadir, Y. (2018). Anti corruption attitude of students as a corruption measure of criminal measures. Substantive Justice International Journal of Law, 1(2), 114-128. https://substantivejustice.id/index.php/sucila/article/view/19 
Kamaruddin. (2016). Membangun kesadaran dan ketaatan hukum masyarakat perspektif law enforcement. Jurnal Al-'Adl, 9(2), 143-157. https://ejournal.iainkendari.ac.id/index.php/al$\mathrm{adl} /$ article/view/683

Komalasari, K., \& Saripudin, D. (2015). Integration of anti-corruption education in school's activities. American Journal of Applied Sciences, 12(6), 445-451. https://doi.org/10.3844/ajassp.2015.445.451

Kristiono, N. (2018). Penanaman karakter anti korupsi melalui mata kuliah pendidikan anti korupsi bagi mahasiswa Fakultas IImu Sosial Universitas Negeri Semarang. Jurnal Hibualamo: Seri IImu-IImu Sosial Dan Kependidikan, 2(2), 51-56. https://journal.unhena.ac.id/index.php/HibSos/article/view/68

Lickona, T. (2009). Educating for character: How our schools can teach respect and responsibility. Bantam Books.

Mahpudz, A. (2020). Pembinaan nilai karakter antikorupsi di perguruan tinggi berlandaskan nilainilai Pancasila. Prosiding Seminar Nasional Kewarganegaraan, July, 39-44.

Manurung, E. H., \& Heliany, I. (2020). Tindakan preventif yang harus dilakukan dalam menumbuhkan pendidikan antikorupsi bagi generasi muda. JURNAL USM LAW REVIEW, 3(1), 219. https://doi.org/10.26623/julr.v3i1.2381

Marlina, Evanirosa, \& Wajnah. (2020). Implementation of anti-corruption education in Piaud Study Program in IAIN Takengon. Budapest International Research and Critics Institute-Journal (BIRCl-Journal), 3(4), 3126-3136. https://doi.org/10.33258/birci.v3i4.1341

Nurgiansah, T. H. (2021). Pendidikan Pancasila sebagai upaya membentuk karakter jujur. Jurnal Pendidikan Kewarganegaraan Undiksha, 9(1), 33-41. https://doi.org/10.23887/jpku.v9i1.31424

Nurgiansah, T. H., Widyastuti, T. M., \& Khoerudin, C. M. (2020). Membangun Kesadaran Hukum Mahasiswa PPKn UPY Dalam Berlalu Lintas. Civic Edu: Jurnal Pendidikan Kewarganegaraan Universitas Pasundan, 2(2), 97-102. https://doi.org/10.23969/civicedu.v2i2.1491

Prasetiyo, W. H., Ishak, N. A., Basit, A., Dewantara, J. A., Hidayat, O. T., Casmana, A. R., \& Muhibbin, A. (2020). Caring for the environment in an inclusive school: The Adiwiyata Green School program in Indonesia. Issues in Educational Research, 30(3), 1040-1057. http://www.iier.org.au/iier30/prasetiyo.pdf

Pritaningtias, D. W., Barendriyas, A. S., Sabela, A. R., \& Utari, I. S. (2019). Implementation of anticorruption education through penetrasi method (Penanaman 9 nilai karakter anti korupsi) for the urban village community of Jabungan. Indonesian Journal of Advocacy and Legal Services, 1(1), 45-64. https://doi.org/10.15294/ijals.v1i1.33752

Project Against Corruption in Albania (PACA). (2012). Education against corruption: A manual for teachers (Issue September). European Union; Council of Europe; Project Against Corruption in Albania (PACA).

Rachmahana, R. S. (2008). Psikologi humanistik dan aplikasinya dalam pendidikan. El-Tarbawi, 1(1), 99-114. https://doi.org/10.20885/tarbawi.vol1.iss1.art8

Salistina, D. (2015). Pendidikan anti korupsi melalui hidden curriculum dan pendidikan moral. Ta'allum: Jurnal Pendidikan Islam, 3(2), 163-184. https://doi.org/10.21274/taalum.2015.3.2.163-184 
Sarmini, Swanda, I. D, \& Nadiroh, U. (2018). The importance of anti corruption education teaching materials for the young generation. Journal of Physics: Conference Series, 953, 012167. https://doi.org/10.1088/1742-6596/953/1/012167

Serfontein, E., \& Waal, E. de. (2015). The corruption bogey in South Africa: Is public education safe? South African Journal of Education, 35(1), 1-12. http://www.scielo.org.za/scielo.php?script=sci_arttext\&pid=S025601002015000100016\&lng=en\&tlng=en

Setiawan, D. (2013). Peran pendidikan karakter dalam mengembangkan kecerdasan moral. Jurnal Pendidikan Karakter, 3(1), 53-63. https://doi.org/10.21831/jpk.v0i1.1287

Sofwan, M., Setiono, P., Mohamed, A. E., \& SAUDAGAR, F. (2018). Fighting against corruption through character education: The voices of Indonesian primary school teachers. IRJE, 2(2), 86-96. https://doi.org/10.22437/irje.v2i2.6092

Subkhan, E. (2020). Pendidikan antikorupsi perspektif pedagogi kritis. INTEGRITAS: Jurnal Antikorupsi, 6(1), 15-30. https://doi.org/https://doi.org/10.32697/integritas.v6i1.649

Sumaryati. (2020). Penguatan pendidikan antikorupsi perspektif essensialisme. Jurnal Antikorupsi, INTEGRITAS, 6(1), 1-14. https://doi.org/https://doi.org/10.32697/integritas.v6i1.408

Suryani, I. (2017). Penanaman nilai-nilai anti korupsi di lembaga pendidikan perguruan tinggi sebagai upaya preventif pencegahan korups. Jurnal Visi Komunikasi, 12(2), 306-323. https://doi.org/10.22441/jvk.v12i2.413

Widoyoko, J. D. (2016). Menimbang peluang Jokowi memberantas korupsi: Catatan untuk gerakan anti korupsi. INTEGRITAS: Jurnal Antikorupsi, 2(1), 269-297. https://doi.org/10.32697/integritas.v2i1.134 